\title{
PENINGKATAN KEMAMPUAN LITERASI MATEMATIKA SISWA MELALUI PENERAPAN MODEL PEMBELAJARAN PROBLEM BASED LEARNING DI KELAS VII SMP NEGERI 5 PALLANGGA KABUPATEN GOWA
}

\author{
Nur Indah'), Sitti Mania'2), Nursalam ${ }^{3)}$ \\ 1,2,3Fakultas Tarbiyah dan Keguruan UIN Alauddin Makassar \\ 1,2,3Kampus II: Jalan H. M. Yasin Limpo Nomor 36 Samata-Gowa \\ E-mail: nurindah@yahoo.com ${ }^{1)}$, sitti_mania@yahoo.com²), \\ nursalam_ftk@uin-alauddin.ac.id ${ }^{3)}$
}

\begin{abstract}
Abstrak:
Penelitian ini bertujuan untuk mengetahui tingkat kemampuan literasi matematika siswa kelas VII SMP Negeri 5 Pallangga sebelum dan setelah penerapan model pembelajaran Problem Based Learning. Metode penelitian ini adalah Kuantitatif dan jenis penelitian Quasi Eksperimen dengan desain penelitian One Group Pretest-Posttest Design. Teknik analisis yang digunakan adalah analisis statistik deskriptif dan analisis statistik inferensial. Hasil penelitian menunjukkan bahwa terdapat peningkatan kemampuan literasi matematika siswa setelah penerapan model pembelajaran Problem Based Learning di kelas VII SMP Negeri 5 Pallangga Kabupaten Gowa. Hal ini berdasarkan hasil analisis data menggunakan statistik deskriptif untuk kemampuan literasi matematika siswa sebelum penerapan model pembelajaran Problem Based Learning memiliki persentase 50\% untuk kategori sedang dan $50 \%$ berada pada kategori rendah. Kemudian untuk kemampuan literasi matematika siswa setelah penerapan model pembelajaran Problem Based Learning memiliki persentase 5\% untuk kategori sedang, $90 \%$ berada pada kategori rendah,dan 5\% berada pada kategori tinggi. Adapun hasil analisis statistik inferensial (Paired Sample T-test) diperoleh nilai signifikansi $<0.05$ yang artinya, terdapat peningkatan kemampuan literasi matematika siswa setelah penerapan model pembelajaran Problem Based Learning di kelas VII SMP Negeri 5 Pallangga Kabupaten Gowa.
\end{abstract}

Kata Kunci: Kemampuan Literasi, Problem Based Learning

$\square$ emakin berkembangnya teknologi informasi saat ini menyebabkan berbagai perubahan terjadi diberbagai lini kehidupan. Perkembangan juga merambah dalam dunia pendidikan. Berdasarkan hal tersebut, maka proses pendidikan haruslah dapat dijalankan sesuai dengan ketentuan yang bersifat mendasar bagi perkembangan ilmu pengetahuan. Perkembangan ilmu pengetahuan teknologi dan sains memberikan 
kemudahan untuk mengakses berbagai ilmu pengetahuan maupun informasi secara cepat, mudah dan akurat dari berbagai sumber. Pembelajaran matematika memegang peranan yang sangat penting dan esensial terhadap perkembangan ilmu pengetahuan, teknologi dan sains tersebut.

Menurut Ojose (2011: 89), matematika merupakan ilmu universal yang mendasari perkembangan teknologi modern, mempunyai peran penting dalam berbagai disiplin dan mengembangkan daya pikir manusia. Perkembangan pesat di bidang teknologi informasi dan komunikasi dewasa ini dilandasi oleh perkembangan matematika di bidang teori bilangan, aljabar, analisis, teori peluang dan matematika diskrit. Untuk menguasai dan mencipta teknologi di masa depan diperlukan penguasaan matematika yang kuat sejak dini.

Menurut Firmansyah (2013), mata pelajaran matematika bertujuan untuk pertama, melatih cara berfikir dan bernalar dalam menarik kesimpulan, misalnya melalui kegiatan penyelidikan, eksplorasi, eksperimen, menunjukkan kesamaan perbedaan, konsistensi, dan inkonsistensi. Kedua, mengembangkan aktivitas kreatif yang melibatkan imajinasi, intuisi, dan penemuan dengan mengembangkan pemikran divergen, orisinil, rasa ingin tahu, membuat prediksi dan dugaan, serta mencoba-coba. Ketiga, mengembangkan kemampuan pemecahan masalah. Keempat, mengembangkan kemampuan menyampaikan informasi atau mengkomunikasikan gagasan antara lain melalui pembicaraan lisan, grafik, peta, diagram, dalam menjelaskan gagasan tersebut

Data dari PISA (Programme for International Student Assessment) tahun 2000, 2003, 2006, 2009 menunjukkan hasil yang tidak banyak berubah pada setiap keikutsertaan. Rata-rata skor prestasi literasi matematika pada PISA tahun 2009, Indonesia hanya menduduki rangking 61 dari 65 peserta dengan rata-rata skor 371, sementara rata-rata skor internasional adalah 496. PISA sendiri merupakan suatu program studi internasional yang bertujuan untuk menguji prestasi literasi membaca, matematika dan sains siswa sekolah berusia antara 15 tahun yang mendekati akhir wajib belajar (Mahdiansyah, 2014: 455).

Fakta bahwa siswa di Indonesia memiliki kemampuan literasi matematika yang masih rendah juga dibuktikan dari hasil wawancara dengan salah satu guru matematika di SMP Negeri 5 yang menyampaikan bahwa sebenarnya belum pernah dilakukan pengujian secara khusus kemampuan 
literasi matematika di SMP Negeri 5 Pallangga, kemampuan literasi matematika siswa di SMP Negeri 5 Pallangga dapat dikatakan masih sangat rendah. Hal ini ditunjukkan dari ketidakmampuan siswa dalam menyelesaikan masalah yang bentuknya merumuskan, menerapkan, bahkan menafsirkan matematika ke dalam berbagai konteks.

Untuk meningkatkan kemampuan literasi matematika siswa di SMP Negeri 5 Pallangga, diperlukan suatu model pembelajaran yang memberi kesempatan seluas-luasnya kepada peserta didik dalam menuangkan ide-ide matematisnya, mengembangkan kemampuan berpikirnya, dan diberi kesempatan untuk mengembangkan masalah yang diberikan oleh guru. Sehingga yang terjadi, siswa akan berusaha untuk menyelesaikan masalahnya dan mengembangkan sendiri masalah tersebut.

Menurut Dzulfikar (2012: 3), Problem Based Learning adalah model pembelajaran dengan pendekatan pembelajaran peserta didik pada masalah autentik sehingga peserta didik dapat menyusun pengetahuannya sendiri, menumbuhkembangkan keterampilan yang lebih tinggi dan inkuiri, memandirikan peserta didik, dan meningkatkan kepercayaan diri sendiri

Berdasarkan uraian di atas, dapat disimpulkan bahwa model Problem Based Learning merupakan model pembelajaran yang melibatkan siswa dalam memecahkan masalah nyata. PBL bertujuan agar siswa mendapatkan hak otonom dalam belajar, belajar sendiri; inkuisi dan keterampilan pemecahan masalah; dan itu adalah salah satu pendekatan dimanaa individu dihadapkan dengan simulasi situasi seperti yang mungkin akan dihadapi dalam kehidupan sehari-hari dan didorong untuk belajar secara individual melalui belajar sendiri dan penelitian.

Oleh karena itu, penulis beranggapan bahwa dengan diterapkannya model Problem Based Learning dapat memberikan solusi pada guru mata pelajaran matematika kelas VII SMP Negeri 5 Pallangga Kec. Pallangga Kab. Gowa dalam meningkatkan kemampuan literasi matematika siswa untuk pelajaran matematika.

\section{PENGERTIAN LITERASI}

Literasi yang dalam bahasa Inggrisnya literacy berasal dari bahasa Latin littera (huruf) yang pengertiannya melibatkan penguasaan sistem-sistem tulisan dan konvensi-konvensi yang menyertainya. Kendati demikian, literasi utamanya berhubungan dengan bahasa dan bagaimana bahasa itu digunakan, 
sementara sistem bahasa tulis itu sifatnya sekunder (Mahdiansyah, 2014: 455).

Kern (2002: 3), literasi adalah penggunaan praktik-praktik situasi sosial, dan historis, serta kultural dalam menciptakan dan menginterpretasikan makna melalui teks. Literasi memerlukan setidaknya sebuah kepekaan yang tak terucap tentang hubungan-hubungan antara konvensi-konvensi tekstual dan konteks penggunaanya serta idealnya kemampuan untuk berefleksi secara kritis tentang hubungan-hubungan itu. Karena peka dengan maksud atau tujuan, literasi itu bersifat dinamis -tidak statis- dan dapat bervariasi di antara dan di dalam komunitas dan kultur diskursus atau wacana. Literasi memerlukan serangkaian kemampuan kognitif, pengetahuan bahasa tulis dan lisan, pengetahuan tentang genre, dan pengetahuan kultural

Literasi menurut PISA (Programe for International Student Assesment) (2006) dianggap sebagai pengetahuan dan keterampilan untuk kehidupan orang dewasa. Literasi diperoleh melalui proses sepanjang hayat, berlangsung tidak hanya di sekolah atau melalui pendidikan formal, tetapi juga melalui interaksi dengan teman-teman dan masyarakat secara luas. Jadi, dapat disimpulkan bahwa literasi diperoleh melalui proses sepanjang hayat, bersifat dinamis dan terus berkembang, berlangsung bukan hanya dalam lingkungan sekolah, namun juga melalui interaksi di lingkungan masyarakat secara luas (Sujana, 2014: 7).

\section{LITERASI MATEMATIKA}

Menurut Ojose (2011: 89), literasi matematika merupakan sebuah pengetahuan untuk mengetahui dan menerapkan dasar matematika dalam kehidupan sehari-hari. Literasi matematika tidak menyiratkan pengetahuan rinci seperti kalkulus, persamaan diferensial, topologi, analisis, aljabar linear, aljabar abstrak dan formula matematika yang kompleks dan canggih, melainkan sebuah pengertian secara luas tentang pengetahuan dan apresiasi matematika yang mampu dicapai

Draft Assessment framework PISA (2012) mendefinisikan literasi matematika sebagai berikut:

"Literasi atau melek matematika didefinisikan sebagai kemampuan seseorang individu merumuskan, menggunakan, dan menafsirkan matematika dalam berbagai konteks. Termasuk di dalamnya bernalar secara matematis dan menggunakan konsep, prosedur, fakta, dan alat matematika dalam membantu seseorang untuk 
mengenal peran matematika dalam dunia dan membuat pertimbangan maupun keputusan yang dibutuhkan sebagai warga Negara"(Astuti, 2014:400).

Menurut Mahdiansya (2014: 456), pembelajaran literasi dicirikan dengan tiga $\mathrm{R}$, yakni responding, revising, dan reflecting. Dalamhal ini, responding melibatkan kedua belah pihak, baik guru maupun siswa. Para siswa memberi respon pada tugas-tugas yang diberikan guru atau pada teks-teks yang mereka baca. Demikian pula guru memberi respon pada jawaban-jawaban siswa agar mereka dapat mencapai tingkat kebenaran yang diharapkan. Pemberian respon atas hasil pekerjaan siswa juga cukup penting agar mereka tahu apakah mereka sudah mencapai hal yang diharapkan atau belum. Revision yang dimaksud di sini mencakup berbagai aktivitas berbahasa. Misalnya, dalam menyusun sebuah laporan kegiatan, revisi dapat dilaksanakan pada tataran perumusan gagasan, proses penyusunan, dan laporan yang tersusun. Reflecting berkenaan dengan evaluasi terhadap apa yang sudah dilakukan, apa yang dilihat, dan apa yang dirasakan ketika pembelajaran dilaksanakan.

\section{PEMBELAJARAN PROBLEM BASED LEARNING}

Problem Based Learning (PBL) dimulai di McMaster University Medical School lebih dari 25 tahun yang lalu. Sejak itu telah diterapkan di berbagai program sarjana dan pasca sarjana di seluruh dunia. Selain itu, sekolah dasar dan menengah juga telah mengadopsi PBL. Pendekatan PBL sekarang sedang digunakan di berbagai perguruan tinggi juga. PBL menggambarkan lingkungan belajar dimana masalah mendorong pembelajaran (Padmavanthy, 2013: 47).

Rusman (2015: 232), mengemukakan bahwa pembelajaran berbasis masalah merupakan penggunaan berbagai macam kecerdasan yang diperlukan untuk melakukan konfrontasi terhadap tantangan dunia nyata, kemampuan untuk menghadapi segala sesuatu yang baru dan kompleksitas yang ada. Karakteristik pembelajaran berbasis masalah adalah sebagai berikut:

a. Pembelajaran menjadi starting point dalam belajar;

b. Permasalahan yang diangkat adalah permasalahan yang ada di dunia nyata yang tidak terstruktur;

c. Permasalahan membutuhkan perspektif ganda (multiple prespective);

d. Permasalahan, menantang pengetahuan yang dimiliki oleh siswa, sikap dan kompetensi yang kemudian kompetensi yang kemudian membutuhkan identifikasi kebutuhan belajar dan bidang baru dalam belajar; 
e. Belajar pengarahan diri menjadi hal yang utama;

f. Pemanfaatan sumber pengetahuan yang beragam, penggunaannya, dan evaluasi sumber informasi merupakan proses yang esensial dalam PBM;

g. Belajar adalah kolaboratif, komunikasi dan kooperatif;

h. Pengembangan keterampilan inquiry dan pemecahan masalah sama pentingnya dengan penguasaan isi pengetahuan untuk mencari solusi dari sebuah permasalahan;

i. Keterbukaan proses dalam PBM meliputi sintesis dan integrasi dari sebuah proses belajar; dan

j. PBM melibatkan evaluasi daireview pengalaman siswa dan proses belajar.

Menurut Wulandari (2013), Problem Based Learning adalah kurikulum dan proses pembelajaran. Dalam kurikulumnya, dirancang masalah-masalah yang menuntut siswa mendapatkan pengetahuan yang penting, membuat mereka mahir dalam memecahkan masalah dan memiliki strategi belajar sendiri serta dapat berpartisipasi dalam tim. Proses pembelajarannya menggunakan pendekatan yang sistematik untuk memecahkan masalah atau menghadapi tantangan yang nanti diperlukan dalam kehidupan sehari-hari.1 Dalam memecahkan masalah yang ada di dunia nyata, kita perlu menyadari bahwa seluruh proses kognitif dan aktivitas mental yang terlibat di dalamnya.

PBL memiliki karakteristik berpusat pada siswa didesain berdasarkan masalah nyata yang open ended atau ambigu, dan mendorong siswa membangun pemahaman yang kaya konsep matematika kontekstual melalui serangkaian pertanyaan yang bersifat konstruktif.

Menurut Putra (2012: 23), memaparkan sintaks pembelajaran Problem Based Learning meliputi 5 fase sebagai berikut:

a. Mengorientasikan siswa pada masalah. Guru menjelaskan tujuan/ kompetensi yang ingin dicapai, menjelaskan logistik yang diperlukan, memotivasi siswa terlibat dalam aktivitas pemecahan masalah yang dipilih.

b. Mengorganisir siswa untuk belajar. Guru membantu siswa mendefinisikan dan mengorganisasikan tugas belajar yang berhubungan dengan masalah tersebut

c. Membimbing penyelidikan/inkuiri individu maupun kelompok. Guru mendorong siswa untuk mengumpulkan informasi yang sesuai,

Bekti Wulandari, "Pengaruh Problem Based Learning terhadap Hasil Belajar Ditinjau dari MOtivasi Belajar PLC di SMK": h.181 
melaksanakan eksperimen untuk mendapatkan penjelasan dan pemecahan masalah.

d. Mengembangkan dan menyajikan hasil karya. Guru membantu siswa dalam merencanakan dan menyiapkan karya yang sesuai seperti laporan, video, atau model, dan membantu mereka untuk berbagi tugas dengan temannya.

e. Menganalisis dan mengevaluasi proses pemecahan masalah. Guru membantu siswa untuk melakukan refleksi atau evaluasi terhadap penyelidikan mereka dan proses-proses yang mereka gunakan.

Dari langkah-langkah yang telah dikemukakan terlihat bahwa pembelajaran berbasis masalah secara umum telah mengakomodasi kebutuhan pembelajaran yang dapat mengembangkan kemampuan literasi matematika siswa. Studi kasus Pembelajaran Berbasis Masalah , meliputi: 1) penyajian masalah; 2) menggerakkan inquiry; 3) langkah-langkah PBM, yaitu analisis inisial, mengangkat isu-isu belajar; iterasi kemandirian dan kolaborasi pemecahan masalah, integrasi pengetahuan baru, penyajian solusi dan evaluasi (Rusman, 2014: 233).

\section{METODE PENELITIAN}

Pendekatan yang digunakan peneliti adalah pendekatan kuantitatif. Dimana penelitian kuantitatif adalah jenis penelitian yang menghasilkan penemuan-penemuaan yang dapat dicapai (diperoleh) dengan menggunakan prosedur-prosedur statistik atau cara-cara lain dari kualifikasi (pengukuran). Penelitian ini merupakan penelitian Quasi Eksperimen, bentuk desain ini merupakan pengembangan dari True Experimental Design, yang sulit dilaksanakan. Desain eksperimental semu bertujuan untuk memperoleh informasi yang merupakan perkiraan bagi informasi yang dapat diperoleh dengan eksperimen yang sebenarnya dalam keadaan yang tidak memungkinkan untuk mengontrol dan/atau memanipulasi semua variabel yang relevan. Desain penelitian yang digunakan adalah One Group PretestPosttest Design.Dalam rancangan ini digunakan satu kelompok subjek. Pertama-tama dilakukan pengukuran (pretest), lalu dikenakan perlakuan dalam hal ini penerapan model Problem Based Learning untuk jangka waktu tertentu, kemudian dilakukan pengukuran untuk kedua kalinya (posttest).

Populasi yang dimaksud dalam penelitian ini adalah seluruh siswa kelas VII SMP Negeri 5 Pallangga Kab. Gowa Tahun Ajaran 2015/2016 dengan jumlah 277 orang yang terdiri dari 7 kelas. Sampel yang menjadi 
subjek penelitiannya adalah siswa Kelas VII E dengan jumlah siswa 40 orang terpilih sebagai kelas penelitian. Adapun instrumen yang digunakan dalam penelitian ini adalah tes kemampuan literasi matematika. Tes akan diberikan dalam bentuk soal essai. Ada dua macam statistik yang digunakan untuk analisis data dalam penelitian, yaitu statistik deskriptif dan statistik inferensial. Uji prasyarat dalam penelitian ini adalah uji normalitas selanjutnya pengujian hipotesis.

\section{HASIL PENELITIAN DAN PEMBAHASAN}

Deskripsi Kemampuan Literasi Matematika Siswa yang Belajar dengan menggunakan Model Pembelajaran Problem Based Learning Pada Kelas VIIE

Berdasarkan hasil penelitian yang telah dilaksanakan di SMP Negeri 5 Pallangga Kabupaten Gowa. Nilai tes kemampuan literasi matematika yang diberikan pada peserta didik sebelum dan setelah penerapan model pembelajaran Problem Based Learning di kelas VII E SMP Negeri 5 Pallangga telah diolah dengan SPSS versi 20 dan diperoleh hasil sebagai berikut:

Tabel 1. Nilai Statistik Dekriptif Hasil Pretest dan Posttest

\begin{tabular}{ccc}
\hline \multirow{2}{*}{ Statistik } & \multicolumn{2}{c}{ Nilai kelas VII E } \\
\cline { 2 - 3 } & Pretest & Posttest \\
\hline Jumlah sampel & 40 & 40 \\
Nilai terendah & 30,00 & 40,00 \\
Nilai tertinggi & 55,00 & 65,00 \\
Nilai rata-rata & 43,70 & 51,35 \\
Standar deviasi & 6,669 & 5,825 \\
\hline
\end{tabular}

Sebelum diterapkan model pembelajaran Problem Based Learning, dilakukan test awal (pretest) dengan hasil nilai terendah yang diperoleh pada kelas VII E adalah 30,00 dan nilai tertinggi adalah 40,00. Nilai rata-rata yang diperoleh adalah 43,70 dengan standar deviasinya adalah 6,669. Artinya, penyebaran datanya sebagian besar berada pada kumpulan berjarak plus minus 6,669 dari rata-rata. Setelah diterapkan model pembelajaran Problem Based Learning, dilakukan test akhir (posttest) dengan hasil nilai terendah yang diperoleh adalah 40,00 dan nilai tertinggi adalah 65,00. Nilai rata-rata yang diperoleh yaitu 51,35 dengan standar deviasinya adalah 5,825. Artinya, 
penyebaran datanya sebagian besar berada pada kumpulan berjarak plus minus 5,825 dari rata-rata.

Berdasarkan hasil pretest dan posttest pada kelas VII E diperoleh nilai rata-rata kemampuan literasi matematika meningkat, yakni nilai rata-rata pretest adalah 43,70 sedangkan nilai rata-rata posttest adalah 51,35.

Tabel 2. Distribusi Frekuensi dan Presentase serta Pengkategorian Skor Hasil Pretest dan Posttest Siswa Kelas VII E

\begin{tabular}{cccccc}
\hline Tingkat & & \multicolumn{2}{c}{ Pretest } & \multicolumn{2}{c}{ Posttest } \\
\cline { 3 - 6 } Penguasaan & Kategori & Frekuensi & $\begin{array}{c}\text { Presentase } \\
\mathbf{( \% )}\end{array}$ & Frekuensi & $\begin{array}{c}\text { Presentase } \\
\mathbf{( \% )}\end{array}$ \\
\hline $\mathbf{0 - 2 0}$ & Sangat & 0 & 0 & 0 & 0 \\
& rendah & & & & \\
$\mathbf{2 1 - 4 0}$ & Rendah & 20 & 50 & 2 & 5 \\
$\mathbf{4 1 - 6 0}$ & Sedang & 20 & 50 & 36 & 90 \\
$\mathbf{6 1 - 8 0}$ & Tinggi & 0 & 0 & 2 & 5 \\
$\mathbf{8 1 - \mathbf { 1 0 0 }}$ & Sangat & 0 & 0 & 0 & 0 \\
& Tinggi & & & & \\
\hline Jumlah & 5 & 40 & 100 & 40 & 100 \\
\hline
\end{tabular}

Berdasarkan tabel di atas maka dapat diketahui bahwa tingkat penguasaan materi siswa pada pretest dan posttest sebagai berikut:

a. Pada pretest tidak terdapat siswa pada kategori sangat rendah, 20 siswa (50\%) berada pada kategori rendah artinya setengah dari jumlah siswa hanya mampu menggunakan rumus matematika, 20 siswa (50\%) berada pada kategori sedang artinya hanya 50\% siswa yang mampu menggunakan rumus, dan melaksanakan prosedur sederhana, dan $0 \%$ hasil pretest siswa berada pada kategori tinggi dan sangat tinggi atau dapat dikatakan bahwa belum ada siswa yang mampu memenuhi semua indikator kemampuan literasi matematika.

b. Pada Posttest terdapat $0 \%$ siswa berada pada kategori sangat rendah, 2 siswa $(5 \%)$ berada pada kategori rendah artinya 5\% siswa hanya mampu menggunakan rumus matematika, 36 siswa (90\%) berada pada kategori sedang artinya hampir semua siswa telah mampu menggunakan rumus, dan melaksanakan prosedur sederhana, 2 siswa berada pada kategori tinggi artinya hanya ada 5\% siswa yang mampu menggunakan informasi yang relevan dari soal, menggunakan rumus dan mampu melaksanakan prosedur sederhana untuk menjawab pertanyaan. Tidak terdapat siswa 
$(0 \%)$ yang berada pada kategori sangat tinggi artinya belum ada siswa yang mampu memenuhi semua indikator kemampuan literasi matematika.

\section{Perbedaan Kemampuan Literasi Matematika Sebelum dan Setelah Penerapan Model Pembelajaran Problem Based Learning pada Siswa Kelas VII E SMP Negeri 5 Pallangga Kabupaten Gowa.}

Pada bagian ini dilakukan analisis statistik inferensial untuk mengetahui apakah ada perbedaan yang signifikan terhadap penerapan model pembelajaran Problem Based Learning terhadap kemampuan literasi matematika siswa kelas VII E SMP Negeri 5 Pallangga Kabupaten Gowa atau tidak. Penulis melakukan analisis dengan melihat data posttest yang diperoleh.

a. Uji Normalitas

Pengujian normalitas bertujuan untuk menyatakan apakah data skor kemampuan literasi matematika pokok bahasan segitiga dan segiempat untuk kelas VII E dari populasi berdistribusi normal. Pengujian normal atau tidaknya data pada penelitian ini menggunakan statistik SPSS versi 20 melalui uji Kolmogorov Smirnov.

Berdasarkan uji normalitas dengan menggunakan uji KolmogorovSmirnov di atas diperoleh nilai signifikan sebesar 0,058 untuk pretest dan 0,288 untuk posttest. Jadi, hasil yang diperoleh lebih besar dari 0,05, maka dapat disimpulkan bahwa data berdistribusi secara normal.

\section{b. Uji Hipotesis}

Uji hipotesis dengan menggunakan uji Paired Sample T-test bertujuan untuk menetapkan ada tidaknya peningkatan yang signifikan antara skor kemampuan literasi matematika siswa yang dicapai sebelum dan setelah diterapkannya model pembelajaran Problem Based Learning. Dengan demikian dirumuskan hipotesis statistik sebagai berikut:

1. Hipotesis Nihil $\left(H_{0}\right)=$ jika $t_{\text {hitung }}<t_{\text {tabel }}$ dan nilai Sig.hitung $>\alpha(0.05)$, maka tidak terdapat perbedaan yang signifikan antara kemampuan literasi matematika siswa kelas VII E SMP Negeri 5 Pallangga Kabupaten Gowa sebelum dan setelah penerapan model pembelajaran Problem Based Learning.

2. Hipotesis Alternatif $\left(H_{1}\right)=$ jika nilai thitung $>t_{\text {tabel }}$ danSig. hitung $_{\text {. }}<\alpha(0.05)$, maka terdapat perbedaan yang signifikan antara kemampuan literasi matematika siswa kelas VII E SMP Negeri 5 Pallangga Kabupaten Gowa 
sebelum dan setelah penerapan model pembelajaran Problem Based Learning.

Teknik pengujian yang digunakan adalah uji Paired Sample T-testdengan taraf signifikan $\alpha=0$,05.Berdasarkan hasil perhitungan Statistical Package For Social Science (SPSS) diperoleh nilai signifikan $=0,000$ sehingga dapat disimpulkan bahwa $\mathrm{H}_{0}$ ditolak dan $\mathrm{H}_{1}$ diterima karena nilai sig $<\alpha \quad(0,000<$ 0,05). Jadi, terdapat perbedaan yang signifikan antara kemampuan literasi matematika siswa kelas VII E SMP Negeri 5 Pallangga Kabupaten Gowa sebelum dan setelah penerapan model pembelajaran Problem Based Learning.

Penelitian yang dilaksanakan di SMP Negeri 5 Pallangga Kabupaten Gowa bertujuan untuk mengetahui tingkat kemampuan literasi matematika siswa dengan menerapkan model pembelajaran Problem Based Learning pada pembelajaran matematika kelas VII tahun ajaran 2015/2016. Sampel dalam penelitian ini adalah kelas VII E dengan jumlah 40 siswa.

Dari penelitian ini diperoleh hasil bahwa terdapat peningkatan kemampuan literasi matematika siswa yang signifikan setelah penerapan model pembelajaran Problem Based Learning. Hal ini sesuai dengan penelitian yang dilakukan oleh Afit Istiandaru yang mengungkapkan bahwa pembelajaran yang menerapkan Problem Based Learning dengan asesmen berorientasi PISA dapat meningkatkan kemampuan literasi matematika siswa.

Penelitian ini juga didukung oleh penelitian terdahulu yang dilakukan oleh Gunantara yang meneliti tentang peningkatan kemampuan pemecahan masalah matematika siswa dengan penerapan model pembelajaran Problem Based Learning dengan hasil penelitian bahwa dengan menerapkan model Problem Based Learning kemampuan pemecahan masalah matematika siswa dapat meningkat.

Peningkatan kemampuan literasi matematika siswa diakibatkan oleh beberapa faktor. Salah satunya adalah langkah-langkah pembelajaran yang berbeda. Pengajaran berdasarkan masalah merupakan pendekatan yang efektif untuk pengajaran proses berpikir tingkat tinggi. Pembelajaran ini membantu siswa untuk memproses informasi yang sudah jadi dalam benaknya dan menyusun pengetahuan mereka sendiri tentang dunia sosial dan sekitarnya. Pembelajaran ini cocok untuk mengembangkan pengetahuan dasar maupun kompleks.

PBL memiliki karakteristik berpusat pada siswa, didesain berdasarkan masalah nyata yang mendorong siswa membangun pemahaman yang kaya konsep matematika kontekstual melalui serangkaian pertanyaan yang bersifat 
konstruktif. Model pembelajaran Problem Based Learning adalah proses pembelajaran yang berpusat pada siswa, sementara sebelum penerapan Problem Based Learning pendidik masih menggunakan proses pembelajaran yang hanya berpusat pada guru. Model pembelajaran yang melibatkan siswa dalam memecahkan masalah nyata dapat menyebabkan motivasi dan rasa ingin tahu menjadi meningkat, sehingga meningkat pula kemampuan literasi matematika siswa.

\section{SIMPULAN}

Berdasarkan hasil penelitian yang diperoleh, dapat disimpulkan bahwa penerapan model pembelajaran Problem Based Learning dapat meningkatkan kemampuan literasi matematika pada materi segitiga dan segiempat siswa kelas VII di SMP Negeri 5 Pallangga Kabupaten Gowa. Peningkatan kemampuan literasi matematika tersebut dapat dilihat pada nilai rata-rata siswa sebelum penerapan model pembelajaran Problem Based Learning (pretest) yaitu sebesar 43,70 sementara setelah penerapan model pembelajaran Problem Based Learning nilai rata-rata siswa (posttest) mengalami peningkatan yaitu 51,35 .

\section{DAFTAR PUSTAKA}

Astuti, R. (2014). Kooperatif tipe TAPPS dan TSTS terhadap kemampuan menyelesaikan soal cerita matematika ditinjau dari tipe kepribadian. Jurnal Nasional, 4, 399-410.

Dzulfikar , A. (2012). Keefektifan problem based learning dan model eliciting. Jurnal Pendidikan, 1, 1-6.

Firmansyah. Pentingnya pembelajaran matematika dalam kurikulum 2013 http://www.sman1subang.sch.id/html/index.php?id=artikel\&kode=3 $\underline{2}$ (8 Desember 2015).

Kern, R. (2002). Reconciling the language-literatur split through literacy. Jurnal Internasional, 3, 1-7.

Mahdiansyah. (2014). Literasi matematika siswa pendidikan menengah: analisis menggunakan desain tes internasional dengan konteks indonesia. Jurnal Pendidikan, 4, 1-8.

Ojose, B. (2012). Mathematics literacy: are we able to put the mathematics we learn into everyday use. Jurnal Internasional, 1, 89-100. 
Padmavanthy. (2013). Effectiveness of problem based learning in mathematics. International Journal of Education, 1, 45-51.

Putra, T.,T. (2012). Meningkatkan kemampuan berfikir kreatif siswa dengan pembelajaran berbasis masalah. Jurnal Pendidikan. 1, 22-26.

Rusman. (2014). Model-model pembelajaran. Jakarta: Rajawali Pers.

Sujana, A. (2014). Literasi kimia mahasiswa PGSD dan guru IPA sekolah dasar", Jurnal Pendidikan, 1, 99-107.

Wulandari, B. (2013). Pengaruh problem based learning terhadap hasil belajar ditinjau dari motivasi belajar PLC di SMK. Jurnal Pendidikan, 2, 1-7. 